Virus Research

March 2002; 84(1-2) : 151-160

http://dx.doi.org/10.1016/S0168-1702(02)00007-2

(C) 2002 Elsevier Science B.V. All rights reserved
Archimer http://www.ifremer.fr/docelec/ Archive Institutionnelle de l'Ifremer

\title{
Detection of oyster herpesvirus DNA and proteins in asymptomatic Crassostrea gigas adults
}

\author{
Isabelle Arzul, Tristan Renault*, Anne Thébault and André Gérard
}

IFREMER, Laboratoire de Génétique et Pathologie, 17390 La Tremblade, France

*: Corresponding author : Tel.: +33-5-4636-9836; fax: +33-5-4636-3751; email: trenault@ifremer.fr

\begin{abstract}
Since 1972, several herpes-like virus infections have been reported among different bivalve species around the world. Most of these reports involved larvae or juveniles presenting high mortalities. Two case reports of herpes-like viruses concerned adult oysters, Crassostrea virginica in USA and Ostrea angasi in Australia. Molecular techniques including PCR and in situ hybridization (ISH) have been recently developed to detect the oyster herpesvirus genome. In the present study, 30 Pacific oyster, Crassostrea gigas, adults have been analyzed using three different techniques: PCR, ISH and immunochemistry, in order to detect herpesviruses in asymptomatic individuals. PCR and ISH allowed detection of oyster herpesvirus DNA in 93.3 and $86.6 \%$, respectively, of analyzed oysters while polyclonal antibodies allowed detection of viral proteins in $76.6 \%$ of analyzed adult oysters. These results suggest that oyster herpesvirus infects adult oysters with high prevalence and that the virus may persist in its host after primary infection. The detection of viral DNA and viral proteins in the gonad of several individuals supports the hypothesis of a possible vertical transmission of the infection. Lastly, concordance among the three techniques used in this study is discussed.
\end{abstract}

Keywords: Herpesvirus; Crassostrea gigas; Adult oyster; Healthy carrier; DNA; Protein 


\section{Introduction}

Since 1991, herpes-like virus infections have been reported in different parts of the world from various marine mollusc species. Virus detection was often associated with high mortality rates in spat and larvae of farmed bivalves, including Japanese oyster, Crassostrea gigas (Hine et al., 1992 ; Nicolas et al., 1992 ; Renault et al., 1994a and b), European flat oyster, Ostrea edulis (Comps \& Cochennec, 1993 ; Renault et al., 2000a) and Tiostrea chilensis (Hine et al., 1998). Herpes-like viruses have also been observed in larvae clams such as Manila clam, Ruditapes philippinarum (Renault, 1998 ; Renault et al., 2001) and grooved carpet shell, Ruditapes decussatus (Renault \& Arzul, 2001). Although these reports usually involved larvae or spat, fewer herpeslike virus descriptions have been noticed from adult bivalves. The first observation was reported in adult eastern oysters, C. virginica (Farley et al., 1972), which presented lethal disease and intranuclear herpes-like virus particules by transmission electron microscopy when maintained at elevated temperatures. Oysters reared at elevated temperatures suffered a higher mortality rate than control animals. Herpeslike viruses have also been reported in haemocytes of adult flat oysters, $O$. angasi (Hine \& Thorne, 1997). In these animals, transmission electron microscopy examination revealed herpes-like virus particles in eosinophilic intranuclear inclusions. At sampling, oysters presented a low mortality rate, associated with the parasite Bonamia sp. infection.

Therefore, adult bivalves appear less sensitive to herpes-like virus infections compared to young stages. The same observation has been noticed concerning vertebrate herpesviruses, such as fish herpesviruses. High mortality rates and severe diseases affect fingerlings most of the time. The Chanel Catfish Virus (CCV) provokes a fatal disease among young fish Ictalurus punctatus (Plumb, 1973). Nevertheless, CCV was detected in asymptomatic adults (Wise et al., 1988). The Oncorhynchus masou virus (OMV) has also proven to be lethal for salmonid fry whereas it was isolated from ovarian fluid of normal appearing adults (Kimura et al., 1981).

Considering these reports, although no abnormal mortality occured among Crassostrea gigas adults in France, the question arises as to whether bivalve herpeslike viruses are able to persist at this stage without any mortality. If, effectively these viruses persist in their host all their lifetime, the hypothesis of viral vertical transmission from spawners to larvae could take all its reality.

In relation with the observation of larval and spat mortality and the economic importance of shellfish culture, specific and sensitive diagnosis methods including PCR, in situ hybridisation (ISH) and immunochemistry using polyclonal antibodies have been developed to enable a rapid detection of herpes-like viruses. In the same time, the viral genome was characterised and this work allowed to confirm that the virus, now named OsHV-1, belongs to the Herpesviridae family (A.J. Davison, MRC Virology unit, Glasgow, United Kingdom, personal communication). The aims of the present study were first to control the presence or absence of herpesvirus in Crassostrea gigas adults by using three sensitive techniques and secondly, to compare these techniques. 


\section{Material and methods}

\section{Animals}

Thirty Crassostrea gigas adult oysters 3 year old were sampled in August 2000 from a shellfish farm located on the French Atlantic coast, in La Tremblade (Charente Maritime, France). Animals did not present mortality or other symptom of disease at the sampling period. They were distributed per group of ten animals in 40 liter tanks and maintained during five days at the same temperature as recorded on the farm site $\left(20^{\circ} \mathrm{C}\right)$. Each oyster was opened and saggitaly sectioned. One half was fixed in Davidson's fixative for in situ hybridization and immunochemistry analysis, another half was frozen at $-20^{\circ} \mathrm{C}$ for PCR analysis.

\section{Oyster DNA extraction}

$50 \mathrm{mg}$ of frozen gill, mantle and gonad tissues were ground in microtubes, using disposable homogenizer in $500 \mu$ digestion buffer $(100 \mathrm{mM} \mathrm{NaCl}, 1 \mathrm{mM}$ Tris, $25 \mathrm{mM}$ EDTA, SDS $25 \% \mathrm{w} / \mathrm{v}, \mathrm{pH}$ 8) additioned with proteinase $\mathrm{K}(0.4 \mathrm{mg} / \mathrm{ml})$. Samples were incubated overnight at $55^{\circ} \mathrm{C}$. Oyster DNA was then phenol-chloroform extracted, ethanol precipitated, resuspended in $100 \mu \mathrm{l}$ of distilled water, and stored at $-20^{\circ} \mathrm{C}$.

\section{PCR analysis}

PCR analysis was performed using two primer pairs located in two different regions of the viral DNA : B and C. Region B encodes a putative apopotosis inhibitor (Arzul et al., 2001). Region C encodes two proteins of unknown function and, being located in an inverted repeat, is present as two copies in the genome of OsHV-1 (Arzul et al., 2001). The first primer pair, B3 (5'-GTG GAG GTG GCT GTT GAA AT -3') and B2 (5'-CAA CAG CTT TGG AGG TTG GT -3') amplified 332 bp fragments. The second primer pair, C2 (5'-CTC TTT ACC ATG AAG ATA CCC ACC-3') and C6 (5'-GTG CAC GGC TTA CCA TTT TT-3') amplified 710 bp fragments. PCR analysis was carried out as described previously (Renault et al., 2000b). A negative control was incorporated after each six samples. It consisted of $1 \mu$ of deionized distilled water. Ten ng of purified viral DNA was added as positive control for each 12 samples analysed.

A selected C2-C6 PCR product was ligated into linearized pT-Adv vector (Clontech, USA). Plasmid DNA was then transformed into TOP10F' Escherichia coli competent cells. Five selected clones were sequenced using the primer pair C2 and C4 (5'-GCA GTT GTG GTA TAC TCG AGA TTG-3') amplifying 353 bp fragments, as double stranded DNA, with the ABI PRISM ${ }^{\circledR}$ sequencing kit (Perkin Elmer, U.S.A.).

A competitive PCR method was applied to determine the amount of OsHV-1 DNA in gonad samples of three adult oysters using the C2-C6 primer pair. In order to quantitate viral DNA in samples, an internal standard previously developed (Renault, unpublished data) was included in PCR mix. PCR conditions were similar to those described by Renault et al. (2000b). 
In situ hybridisation (ISH)

ISH was performed adapting a previously described protocol (Renault \& Lipart, 1998). DNA probes were produced by PCR according to the above protocol, except $\mathrm{MgCl}_{2} 1.5 \mathrm{mM}$, using viral DNA as template (0.1 ng / PCR reaction), the primer pair C1 (5'-TTC CCC TCG AGG TAG CTT TT-3') and C6, and digoxigenin-11-dUTP (Boehringer Mannheim, Germany) (Renault \& Lipart, 1998). Oyster samples preserved in Davidson's fixative were embedded in paraffin. Seven $\mu \mathrm{m}$ thick sections on silane-prep ${ }^{\mathrm{TM}}$ slides (Sigma, France) were dewaxed, rehydrated and treated with proteinase $\mathrm{K}\left(100 \mu \mathrm{g} / \mathrm{ml}\right.$ in distilled water) at $37^{\circ} \mathrm{C}$ for $15 \mathrm{~min}$. After dehydration, a prehybridisation step was carried out with hybridisation buffer (50\% formamide, 10\% dextran sulfate, 4X SSC [0.06 M NaCitrate, $0.6 \mathrm{M} \mathrm{NaCl}, \mathrm{pH} 7], 250 \mu \mathrm{g} / \mathrm{ml}$ yeast tRNA and $10 \%$ Denhart) for $30 \mathrm{~min}$ at $42^{\circ} \mathrm{C}$ in a humid chamber. The solution was replaced with hybridisation buffer containing digoxigenin-labeled probes $(2.5 \mathrm{ng} / \mu \mathrm{l})$. Slides were covered with plastic coverlips (Polylabo, France) and placed on a heating block at $95^{\circ} \mathrm{C}$ for $5 \mathrm{~min}$ to denature target DNA and digoxigenin-labeled probe. The hybridisation was then performed by incubating slides at $42^{\circ} \mathrm{C}$ overnight in a humid chamber. Sections were washed in $2 \mathrm{X}$ SSC at room temperature $(2 \times 5$ $\mathrm{min}$ ) and in $0.4 \mathrm{X} \mathrm{SSC}$ at $42^{\circ} \mathrm{C}(10 \mathrm{~min})$. Unbound probes were removed by a $5 \mathrm{~min}$ wash in solution I (100 mM maleic acid, $5 \mathrm{M} \mathrm{NaCl}, \mathrm{pH}$ 7.5). Tissues were then blocked for 30 min at room temperature with blocking reagent (Amersham Life Science, France) $(1 \% \mathrm{w} / \mathrm{v})$ in solution I. Bound probes were detected using an alkaline phosphatase-conjugated mouse IgG antibody against digoxigenin diluted 1:500 in solution I for one hour at room temperature. Unbound antibodies were removed by two washes in solution I $(1 \mathrm{~min})$ and one wash in solution II (1 M Tris pH $8,5 \mathrm{M} \mathrm{NaCl}, 1 \mathrm{M} \mathrm{MgCl}_{2}, \mathrm{pH}$ 9). Slides were finally incubated in NBT/BCIP diluted in solution II $(20 \mu \mathrm{l} / 1 \mathrm{ml})$ for $30 \mathrm{~min}$ in the dark. The reaction was stopped with solution III (1M Tris, pH8, 0.5 M EDTA, pH8). Slides were stained for 1 min in Bismarck brown yellow followed by ethanol dehydration and mounted in Eukitt resin. Negative controls included samples without digoxigenin-labeled probes in the hybridisation mixture or without antibodies during the revelation step. Negative controls included also sample hybridisation with a digoxigenin-labeled probe specific to the Spring Viremia of Carp virus (SVCV) supplied by Dr R.M. Le Deuff (CEFAS, Weymouth laboratory, United Kingdom). A positive control consisted in Crassostrea gigas juveniles known as infected by OsHV-1 using TEM and PCR.

\section{Immunochemistry}

Immunochemistry analysis was performed adapting a previously described protocol (Le Deuff, 1995). Polyclonal antibodies have been produced in BalbC mice immunized with viral particles purified from infected Crassostrea gigas larvae (Le Deuff, 1995). Oyster samples preserved in Davidson's fixative were embedded in paraffin. Seven $\mu \mathrm{m}$ sections on silane-prep ${ }^{\mathrm{TM}}$ slides (Sigma, France) were dewaxed, rehydrated and treated one hour in methanol with $\mathrm{H}_{2} \mathrm{O}_{2}(4 \% \mathrm{v} / \mathrm{v})$ in order to inactivate endogenous peroxidases. After blocking tissues for 90 min with dried skim milk (6\% $\mathrm{w} / \mathrm{v})$ and saponin $(0.05 \% \mathrm{w} / \mathrm{v})$ in $1 \mathrm{X}$ PBS $\left(150 \mathrm{mM} \mathrm{NaCl}, 12.5 \mathrm{mM} \mathrm{Na} \mathrm{HPO}_{4}, 3 \mathrm{mM}\right.$ $\mathrm{KH}_{2} \mathrm{HPO}_{4}$, pH 7.5), sections were incubated overnight at $4^{\circ} \mathrm{C}$ with polyclonal antibodies diluted 1:500 in 1X PBS. Unbound antibodies were removed by six washes in 1X PBS (5 min). Bound antibodies were detected using a peroxidaseconjugated antibody against mouse IgG (Sanofi Diagnostic Pasteur, France) diluted 1:400 in 1X PBS for one hour at room temperature. Unbound secondary antibodies 
were removed by six washes in $1 X$ PBS $(5 \mathrm{~min})$. Diaminobenzidine tetrahydrochloride was diluted in $1 X$ PBS $(0.7 \mathrm{mg}$ per $\mathrm{ml}$ ) plus hydrogen peroxide $(0.3 \% \mathrm{v} / \mathrm{v}) .200 \mu \mathrm{l}$ of the colour solution were added on each tissue section and incubation was carried out $10 \mathrm{~min}$ in the dark. The reaction was stopped with two $1 \mathrm{X}$ PBS washes. Slides were stained for $20 \mathrm{sec}$ in Unna Blue (RAL, France) followed by ethanol dehydration and mounted in Eukitt resin. Negative controls included samples without the primary antibody or the secondary antibody. Positive controls consisted in Crassostrea gigas juvenile histological sections known as infected by OsHV-1 using TEM and PCR.

\section{Data analysis}

Virus detection agreement between organs and techniques was estimated by determining the Kappa value according Landis and Koch (1977). In the case of technique comparison, an animal was considered positive by a technique if at least one organ appeared positive by this technique. The distribution of discordance between organs was estimated by using the McNemar's test (McNemar, 1947) which is quite similar to a chi-square with one degree of freedom and with a $F$ value calculated on desagreed pairs. Global agreement between techniques, considering the three organs analysed, was determined using the generalized Kappa (Fleiss, 1981). All data analysis were performed using SAS software, v8.1 (Stokes et al., 1995).

\section{RESULTS}

PCR analysis with the B3-B2 and C2-C6 primers resulted in amplicons of expected size for 19 samples of gills, 16 samples of gonad and 20 samples of mantle. 28 animals presented positive results for at least one organ. Only two individuals presented negative results for all organs analysed (Table1).

One C2-C6 PCR product resulting from the analysis of the gill sample of individual 1 (Table 1) has been sequenced. A 312 bp consensus sequence (Figure 1) totally similar to OsHV-1 DNA has been obtained (Arzul et al., 2001).

A competitive PCR method allowed to detect 1.5 to $325 \mathrm{pg}$ of viral DNA per $0.5 \mathrm{mg}$ of oyster tissues. Analyses were repeated in duplicate for each animal. The data were plotted on a graph (Fig. 2). The equivalence point indicates initial amount of viral DNA in sample. $25 \mathrm{pg}, 1.5 \mathrm{pg}$ and $325 \mathrm{pg}$ of viral DNA were detected in gonad samples from individuals 1,2 and 3 . These amounts correspond approximately to 1.1 $10^{6}, 6.610^{4}$, and $1.410^{7}$ genome copies repectively, assuming a genome size around $206 \mathrm{kpb}$ (A.J. Davison, personal communication).

ISH analysis allowed to detect positive reactions, characterised by purple precipitate, in 26 animals (Figs. 3a and 3b). Similar signal was detected in OsHV-1 infected spat, whereas no signal was detected when the digoxigenin-labeled probes or the antibodies were omitted or when a digoxigenin-labeled probe specific to Spring Viremia of Carp virus (SVCV) was used (data not shown).

Concerning positive adults, hybridisation consistency and signal intensity varied according individuals and tissues. Adults exhibited a reduced infection pattern compared to infected spat. These last presented a strong positive reaction with numerous labeled cells in connective tissues of numerous organs including digestive gland, labial palps and mantle. In adult oysters, purple staining appeared as foci of a 
few cells in connective tissues of gills (16/30; Fig. 3a), gonad (14/30; Fig. 3b), mantle (17/30) and adductor muscle (9/30) (Table 1). Staining was located in the whole cytoplasm and the nucleus of positive cells. Some of the cells presented anomalous patterns of marginated chromatin. In some cases, a signal was also detected in epithelial cells of gills (2/30) (Fig. 3a). Four animals presented negative results by ISH (Table 1).

Immunochemistry using polyclonal antibodies allowed to detect positive reactions, characterised by a brown precipitate, in 23 animals (Figs. 4a, 4b and 4c). Infected spat used as positive controls presented positive cells located in connective tissues of gills, mantle, gonad, digestive gland and labial palps. On the contrary, no signal was obtained when the primary or the secondary antibody was omitted. Similarly to $\mathrm{ISH}$ results, adults presented fainter staining than infected juveniles. Foci of positive cells were observed in gills (14/30 ; Fig. 4a), gonad (10/30 ; Figs. 4b and 4c), mantle (14/30), and adductor muscle (10/30) (Table 1). Brown specific staining was located in the cytoplasm and the nucleus of positive cells. Seven animals appeared negative by this technique (Table 1 ).

On the 30 analysed oysters, $25(83.3 \%)$ presented identical results by the 3 techniques, PCR, ISH and immunohistochemistry. Indeed, 23 animals appeared positive and 2 appeared negative (Table1, animals 11 and 25) with the 3 techniques. Five individuals presented discrepant results (Table1, animals 5, 13, 15, 22 and 28). These 5 individuals appeared negative by immunochemistery, 2 of them appeared positive by ISH while all of them appeared positive by PCR.

Results from the 30 analysed animals were classified as dichotomous response, 0 (negative response) and 1 (positive response) for each organ and each technique. Comparison between organs was realised two by two for each technique by determining the Kappa value (Table 2a). Kappa values were confronted with Landis and Koch numeric scale ( $<0$, poor agreement ; 0-0.2, slight agreement ; 0.2-0.4, fair agreement; 0.6-0.8, substantial agreement; 0.8-1, almost perfect agreement; Landis and Koch, 1977). Comparison of results according the organ analysed presented poor or slight agreement except for gills and mantle analysed by immunochemistry (0.33). All these results were not significant with a level of confidence of 0.95 . Comparison between techniques was performed two by two by estimating the Kappa value (Table 2b). A substantial agreement was observed between PCR and ISH (0.63) and between ISH and immunochemistry (0.67), whereas a moderate agreement was observed between PCR and immunochemistry (0.38) and between the three techniques (0.49). Estimation of agreement between techniques without taking gonad results in account allowed to obtain higher Kappa values (Table $2 \mathrm{~b}$ ). For instance, the Kappa value is 0.58 instead of 0.49 when the three techniques are compared. 


\section{DISCUSSION}

Herpes-like viruses were observed in larvae and spat of several bivalve species, however, a few of herpes-like virus descriptions concerned adult oysters. Herpes-like virus detection reported in 6-day old larvae of $C$. gigas held at elevated temperature and apparent importance of parental origin already suggested a possible vertical transmission of the virus from parents to larvae (Le Deuff et al., 1996). These previous reports inclined us to analyse adult oysters with sensitive molecular techniques currently available.

In vertebrates, diagnosis of viral infections has relied on direct demonstration of the presence of viruses by culture or transmission electron microscopy or by using molecular techniques. As histological lesions are not specific to herpes-like virus infections in diseased oysters and as no bivalve cell line is yet available to allow virus culture, the development of molecular techniques, including PCR (Renault et al., 2000b) and ISH (Renault \& Lipart, 1998), and immunochemistry methods (Le Deuff, 1995) appeared powerfull for diagnosing the now characterised OsHV-1 in oysters. These techniques were first developed and applied to analyse young stages of bivalve since high mortality affect larvae and spat.

In the present study, these techniques were applied to analyse 30 asymptomatic adult oysters. 93.3\% appeared positive by PCR, $86.6 \%$ presented positive results by ISH and $76.6 \%$ by using polyclonal antibodies. The $\mathrm{C} 2-\mathrm{C} 4$ consensus sequence obtained from individual 1 was 100\% homologous with genomic DNA of virus purified from infected Crassostrea gigas larvae (Fig. 1 ; Arzul et al., 2001). There was no longer any doubt about the nature of amplified DNA.

Therefore, the main result of this work is the detection of herpes-like virus using 3 different techniques in asymptomatic Crassostrea gigas adults. Indeed, $76 \%$ of animals appeared positive whatever the technique used. Like most of herpesviruses, OsHV-1 seems to occur at high prevalence in the analysed oyster $C$. gigas population. This result suggests that the virus is able to persist in its host after a primary infection without inducing disease and mortality. This ability to persist is common to all members of the Herpesviridae family, and the question arises as to whether it persists under a latent phase or with a low level of expression. The detection of viral proteins by immunochemistry let think that there is a protein expression. Nevertheless, the specificity of the polyclonal antibodies used in this study is not known. They could detect structural proteins or functional proteins, which does not present the same significance. Moreover, 1.5 to $325 \mathrm{pg}$ of OsHV-1 DNA were detected from $0.5 \mathrm{mg}$ of adult oyster tissues using the competitive PCR method (Fig. 2). These results indicate that amounts of viral DNA vary considerably from an adult oyster to the other one. Such variations were reported concerning amount of pseudorabies virus DNA detected in latently infected pigs (Thiery et al., 1996). Comparison between adult oysters and infected spat indicates that these last present higher amounts of virus DNA (T. Renault, personal communication). $750 \mathrm{pg}$ to 42.5 ng of viral DNA were detected from $0.5 \mathrm{mg}$ of infected spat tissues ( $T$. Renault, personal communication). All members of the Herpesviridae family establish a lifetime presence in a host, involving a range of mechanisms of latency. Among well studied alphaherpesvirinae, many lines of evidence show that Human Herpes Simplex Viruses, HSV1 and HSV2 and Pseudorabies virus (PrV) establish a true 
latent rather than a low level chronic infection. During latency, the lytic cycle promoters of these viruses are silenced, transcription of the viral genome is restricted to latency-associated transcripts (LATs) (Stevens et al., 1987; Cheung, 1990 ; Cheung, 1991). Epstein Barr Virus (EBV) differs from most of other human herpesviruses notably in its extensive gene expression during latent infection (Kieff and Leibowitz, 1990). Unlike other herpesviruses, Varicella Zona Virus (VZV) seems to present an expression of several viral proteins within the cytoplasm of neurons of latently infected ganglia (Lungu et al., 1998). Such mechanisms could also exist in the case of oyster herpesvirus.

Previous works pointed out the hypothesis that OsHV-1 could be present in a latent form in some of the oyster parents and could be activated by stress in these hosts, such as a modification of breeding temperature or manipulation of the animals (Le Deuff et al., 1996). Spawning constitutes a period of stress which could contribute to reactivate the viral replication in adults. Produced virions would then be transmitted to larvae. Vertical transmission is more than suspected. In the present study, positive results were observed on gonad using the 3 techniques. Slides processed by ISH and immunochemistry revealed positive labeled cells in gonad connective tissue (Figs. 3b, 4b and 4c). These cells may probably be released with the gametes in the water and could constitute an early source of virus contamination for oyster embryos. Other « aquatic » herpesviruses have been detected in fluids emitted during the spawning. The Oncorhynchus masou virus was isolated from ovarian fluids of normal appearing adult landlocked masu salmon (Oncorhynchus masou) (Kimura et al., 1981). Nusbaum and Grizzle (1987) suggested that the Chanel Catfish virus adheres to the sperm in the male reproductive system, resulting in transmission of the virus from males to their progeny.

Concerning techniques used in the present study, PCR is confirmed to be the more sensitive method and is likely to be a technique of choice for detecting OsHV-1 DNA in adults. Although the PCR technique is prone to contamination, we adopted meticulous measures to avoid this possibility. All steps of PCR analysis, including sample preparation, preparation of amplification mixture components and PCR amplification were carried out in separate rooms. To check potential contamination, negative controls were incorporated every sixth samples analysed. By comparaison, ISH allowed to detect viral DNA in $86.6 \%$ of animals. This difference can be explained by the fact that PCR is based on an amplification of viral DNA whereas ISH relies on a direct revelation of viral DNA presence. Therefore, PCR is more sesitive than ISH. Three pieces of each animal were analysed by PCR whereas ISH was realised on just one $7 \mu \mathrm{m}$ thick section. Lastly, the immunochemistry method appears a little less sentive than molecular techniques. On the whole, positive signals were detected in same organs by ISH and by using polyclonal antibodies, and presented similar pattern as few spots of positive cells in connective tissue and sometimes in epithelial cells (Fig. 3a). The connective tissue of mantle and gills appears the preferential location for viral detection which agrees with previous observations made on younger stages during acute infections (Renault et al., 1994a and b; Renault et al., 2000a).

In the case of a study turned to determine the status of adult batches, analysis may be led preferably on mantle and gills, whereas if a work is turned to support vertical transmission hypothesis, analysis can be performed on gonads. The poor agreement obtained when considering gonad and the two other organs (gills and mantle) can be explained either by a difficulty to detect viral DNA or viral proteins or either by a weaker infection development in this organ. Even if PCR appears the more sensitive 
method, ISH and immunochemistry allow to observe all organs in a same analysis and to localize exactly viral DNA or proteins. ISH and immunochemistry present quite similar results with a subsantial agreement (Kappa value $=0.67$ ). In a first step of an epidemiological study, ISH could be advised, and negative results could be confirmed or not by PCR.

The present study shows that OsHV-1 DNA and proteins are detected in most of analysed asymptomatic adult oysters. This work allows new approach for the study of this virus, such as a quantitative approach or an epidemiological study of herpesvirus infection in adults. Like other herpesviruses, the OsHV-1 seems to be able to persist in its hosts. Adult oysters may play the role of carriers and reservoirs of the virus, promoting virus transmission from adults to larvae as previously hypothesized (Le Deuff et al., 1996).

\section{Acknowledgements.}

We acknowledge Dr A. Gérard for facilitating this work at the IFREMER Station in La Tremblade, France. We are grateful to Dr. J. R. Bonami for his scientific insights. This research was supported in part by European Union contracts (FA-S2 9052 and FAIRCT-4334). This study would not have been possible without the valuable contribution of French private shellfish farmers. We also thank Dr. R. M. Le Deuff (CEFAS, Weymouth, U.K.) for her valuable critical comments on the manuscript. 


\section{References}

Arzul, I., Renault, T., Lipart, C., Davison, A.J., 2001. Evidence for interspecies transmission of oyster herpesvirus in marine bivalves. J. Gen. Virol. 82, 865-870.

Cheung, A.K., 1990. The BamHI J fragment (0.76to 0.737 map units) of pseudorabies virus is transcriptionaly active during viral infection. J. Virol. 64, 977983.

Cheung , A.K., 1991. Cloning of the latency gene and the early protein $O$ gene of pseudorabies virus. J. Virol. 65, 5260-5271.

Comps, M., Cochennec, N., 1993. A herpes-like virus from the European oyster Ostrea edulis. J. Inv. Pathol. 62, 201-203.

Farley, C. A., Banfield, W. G., Kasnic, J. R. G., Foster, W. S., 1972. Oyster herpestype virus. Science, Wash. D.C. 178, 759-760.

Fleiss, J.L., 1981. Statistical methods for rates and proportions, $2^{\text {nd }}$ edn, John Wiley and Sons (Eds), pp. New York.

Hine, P. M., Thorne, E. T., 1997. Replication of herpes-like viruses in haemocytes of adult flat oysters Ostrea angasi (Sowerby, 1871) : an ultrastructural study. Dis. aquat. Org. 29(3), 197-204.

Hine, P. M., Wesney, B., Besant, P., 1998. Replication of a herpes-like virus in larvae of the flat oyster Tiostrea chilensis at ambient temperatures. Dis. aquat. Org. 32(3), 161-171.

Hine, P. M., Wesney, B., Hay, B. E., 1992. Herpesvirus associated with mortalities among hatchery-reared larval Pacific oysters, Crassostrea gigas. Dis. aquat. Org. 12(2), 135-142.

Kieff, E., Liebowitz D., 1990. Epstein-Barr virus and its replication. In : Fields B.N., Knipe D.M. (Eds), Fields' Virology, $2^{\text {nd }}$ edn. Raven Press, New York, pp. 1889-1920.

Kimura, T., Yoshimizu, M., Tanaka, M., Sannohe, H., 1981. Studies on a new virus (OMV) from Oncorhynchus masou- I. Characteristics and Pathogenicity. Fish Pathol. 15(3/4), 143-147.

Landis, J.R., Koch, G.G., 1977. The measurement of observer agreement for categorical data. Biometrics 33, 159-74.

Le Deuff, R. M., 1995. Contribution à l'étude de virus de mollusques marins apparentés aux Iridoviridae et aux Herpesviridae. Thèse de doctorat. Université de Bordeaux II, pp. 234.

Le Deuff, R. M., Renault, T., Gérard, A., 1996. Effects of temperature on herpes-like virus detection among hatchery-reared larval Pacific oyster Crassostrea gigas. Dis. aquat. Org. 24(2), 149-157. 
Lungu, O., Panagiotidis, C. A., Annunziato, P.W., Gershon, A.A., Silverstein, S.J., 1998. Aberrant intracellular localization of Varicella-Zoster virus regulatory proteins during latency. Proc. Natl. Acad. Sci. USA. 95, 7080-7085.

McNemar, Q., 1947. Note on the sampling error of the difference between correlated proportions or percentages. Psychometrika. 12, 153-157.

Nicolas, J. L., Comps, M., Cochennec, N., 1992. Herpes-like virus infecting Pacific oyster larvae, Crassostrea gigas. Bull. Eur. Ass. Fish Pathol. 12(1), 11-13.

Nusbaum, K. E., Grizzle, J. M., 1987. Adherence of Chanel Catfish Virus to sperm and leukocytes. Aquaculture 65, 1-5.

Plumb, J.A., 1973. Effects of temperature on mortality of fingerling Channel Catfish (Ictalurus punctatus) experimentally infected with Channel Catfish Virus. Journal of fisheries research Board of Canada. 30(4), 568-570.

Renault, T., 1998. Infections herpétiques chez les invertébrés : détection de virus de type herpès chez les mollusques bivalves marins. Virologie. 2, 401-403.

Renault, T., Arzul, I., 2001. Herpes-like virus infections in hatchery-reared bivalve larvae in Europe : Specific viral DNA detection by PCR. J. Fish Dis. 24, 161-167.

Renault, T., Lipart, C., 1998. Diagnosis of herpes-like virus infections in oysters using molecular techniques. In: Aquaculture and Water: Fish Culture, Shellfish Culture and Water Usage, pp. 235-236. European Aquaculture Society, Special Publication $\mathrm{n}^{\circ}$ 26. Compiled by $\mathrm{H}$. Grizel \& P. Kestemont. Oostende, Belgium : European Aquaculture Society.

Renault, T., Lipart, C., Arzul, I., 2001. An herpes-like virus infects a non-ostreid bivalve species : virus replication in Ruditapes philippinarum larvae. Dis. Aquat. Org. 45, $1-7$.

Renault, T., Cochennec, N., Le Deuff, R.M., Chollet, B., 1994b. Herpes-like virus infecting Japanese oyster (Crassostrea gigas) spat. Bull. Eur. Ass. Fish Pathol. 14(2), 64-66.

Renault, T., Le Deuff, R.M., Cochennec, N., Maffart, P., 1994a. Herpesviruses associated with mortalities among Pacific oyster, Crassostrea gigas, in France Comparative study. Revue Méd. Vét. 145(10),735-742.

Renault, T., Le Deuff, R.M., Chollet, B., Cochennec, N., Gérard, A., 2000a. Concomitant herpes-like virus infections among hatchery-reared larvae and nurserycultured spat Crassostrea gigas and Ostrea edulis. Dis. aquat. Org. 42, 173-183.

Renault, T., Le Deuff, R.M., Lipart, C., Delsert, C., 2000b. Developement of a PCR procedure for the detection of a herpes-like virus infecting oysters in France. J. Virol. Meth. 88, 41-50.

Stevens, J.G., Wagner, E.K., Devi Rao, G.B., Cook, M.L., Feldman, L.T., 1987. RNA complementary to a herpesvirus alpha gene mRNA is prominent in latently infected neurons. Science 235, 1056-1059. 
Stokes, M., Davis, C.S., Koch, G.G., 1995. Categorical data analysis using the SAS system, pp 497. SAS Institute, Cary, North Carolina, USA.

Thiery, R., Pannetier, C., Rziha, H.J., Jestin, A., 1996. A fluorescence-based quantitative PCR method for investigation of pseudorabies virus latency. J. Virol. Methods. 61(1-2), 79-87.

Wise, J.A., Harrell, S.F., Busch, L.B., Boyle, J.A., 1988. Vertical transmission of channel catfish virus. Am. J. Vet. Res. 49(9), 1506-1509. 


\begin{tabular}{|c|c|c|c|c|c|c|c|c|c|c|c|}
\hline \multirow[t]{2}{*}{ Oyster } & \multicolumn{3}{|c|}{$\mathbf{P C R}^{\ddagger}$} & \multicolumn{4}{|c|}{ In situ hybridization " } & \multicolumn{4}{|c|}{ Immunochemistry $^{\#}$} \\
\hline & Gi & Go & Ma & Gi & Go & Ma & Mu & Gi & Go & Ma & Mu \\
\hline 1 & + & + & - & + & + & - & + & + & + & - & + \\
\hline 2 & - & + & - & - & + & - & + & - & + & - & + \\
\hline 3 & + & + & + & + & + & + & - & - & + & + & - \\
\hline 4 & + & + & + & + & + & + & - & + & + & + & - \\
\hline 5 & - & - & + & - & - & - & - & - & - & - & - \\
\hline 6 & + & + & + & + & + & + & - & + & + & + & - \\
\hline 7 & - & + & + & - & + & + & + & - & + & + & + \\
\hline 8 & + & - & + & + & - & + & - & + & - & + & - \\
\hline 9 & + & - & + & + & - & + & - & + & - & + & - \\
\hline 10 & + & + & + & - & + & + & - & - & - & + & - \\
\hline 11 & - & - & - & - & - & - & - & - & - & - & - \\
\hline 12 & + & - & + & + & - & + & - & - & - & + & - \\
\hline 13 & - & + & + & - & + & - & - & - & - & - & - \\
\hline 14 & - & + & - & - & + & - & - & - & + & - & + \\
\hline 15 & + & + & - & + & + & - & - & - & - & - & - \\
\hline 16 & - & + & + & - & + & + & + & - & + & + & + \\
\hline 17 & + & - & - & + & - & - & - & + & - & - & - \\
\hline 18 & + & + & - & + & + & - & - & + & - & - & - \\
\hline 19 & + & - & - & + & - & - & + & + & - & - & + \\
\hline 20 & + & + & - & + & + & - & - & + & + & - & - \\
\hline 21 & + & - & + & + & - & + & - & + & - & + & + \\
\hline 22 & + & - & + & - & - & - & - & - & - & - & - \\
\hline 23 & + & - & + & + & - & + & + & + & - & + & + \\
\hline 24 & + & - & + & + & - & + & + & + & - & + & - \\
\hline 25 & - & - & - & - & - & - & - & - & - & - & - \\
\hline 26 & + & + & + & - & - & + & + & + & - & + & + \\
\hline 27 & + & - & + & + & - & + & - & + & - & + & - \\
\hline 28 & - & + & + & - & - & + & - & - & - & - & - \\
\hline 29 & - & - & + & - & - & + & + & - & - & - & + \\
\hline 30 & - & + & + & - & + & + & - & - & + & - & - \\
\hline & 19 & 16 & 20 & 16 & 14 & 17 & 9 & 14 & 10 & 14 & 10 \\
\hline & \multicolumn{3}{|c|}{$28(93.3 \%)$} & \multicolumn{4}{|c|}{$26(86.6 \%)$} & \multicolumn{4}{|c|}{$23(76.6 \%)$} \\
\hline
\end{tabular}

Table 1 - PCR, ISH and immunochemistry results for 30 Crassostrea gigas adult oysters according the organ analysed (Gi : Gills ; Go : Gonads ; Ma : Mantle ; Mu : Addustor muscle).

$F_{+}=$product obtained, $-=$product not obtained

$\#_{+}=$positive reaction observed, $-=$positive reaction not observed 


\begin{tabular}{|l|l|l|l|l|l|l|l|l|l|}
\hline & \multicolumn{4}{|l}{ PCR } & \multicolumn{3}{l|}{ ISH } & \multicolumn{3}{l|}{ Immunochemistry } \\
\hline & Gi/Ma & Gi/Go & Ma/Go & Gi/Ma & Gi/Go & Ma/Go & Gi/Ma & Gi/Go & Ma/Go \\
\hline Kappa & 0.05 & -0.15 & -0.09 & 0.13 & -0.06 & -0.12 & 0.33 & -0.09 & 0.05 \\
\hline Pr & 0.78 & 0.47 & 0.32 & 0.78 & 0.61 & 0.47 & 1.00 & 0.32 & 0.28 \\
\hline
\end{tabular}

Table 2a - Kappa value and McNemar's test between organs for each technique. Pr : significance probability. Gi : Gills ; Ma : Mantle ; Go : Gonads. ISH : In situ hybridization.

\begin{tabular}{|l|l|l|l|l|}
\hline & PCR / ISH & PCR / Immuno & ISH / Immuno & PCR /ISH / Immuno \\
\hline Kappa (with gonad) & 0.63 & 0.38 & 0.67 & 0.49 \\
\hline Kappa (without gonad) & 0.67 & 0.47 & 0.75 & 0.58 \\
\hline
\end{tabular}

Table 2b - Kappa value between techniques with and without taking gonad results in account. ISH : In situ hybridization. Immuno : Immunochemistry.

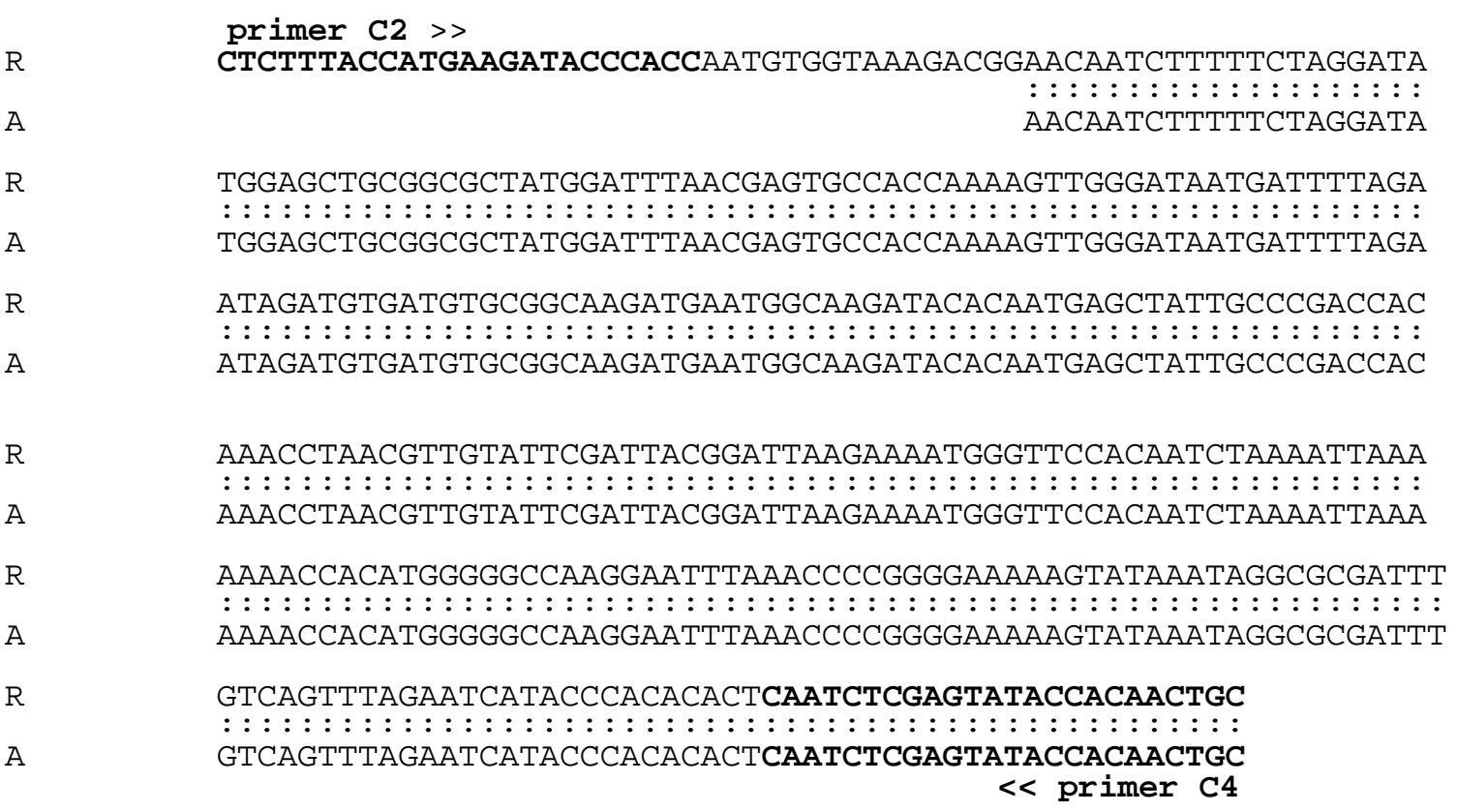

Figure 1 - Reference C2-C4 DNA sequence $(R)$ aligned with the 312 bp sequence from adult sample (A). Primers C2 and C4 are shown with their sequences in bold type. 


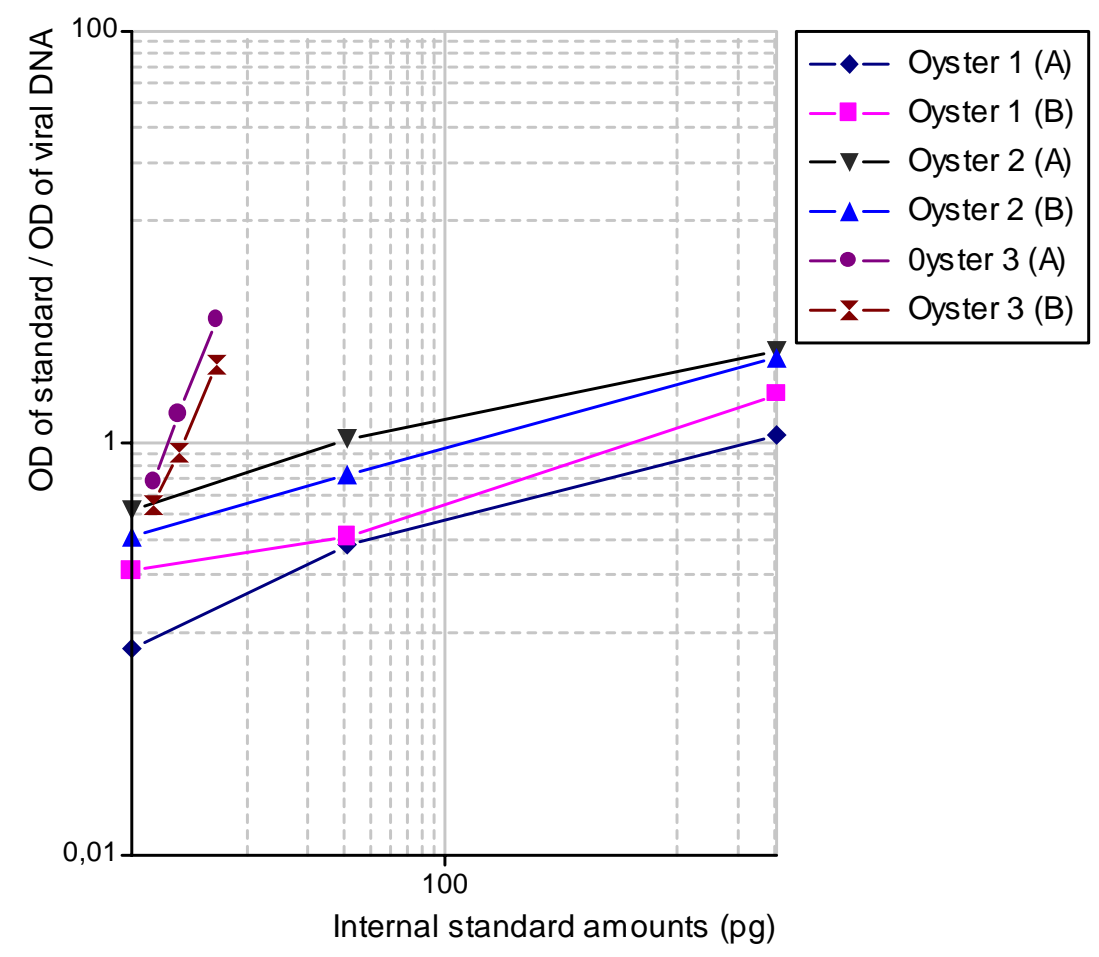

Figure 2 - Quantitation of oyster herpesvirus DNA in adult samples. The amount of viral DNA present in three adult oyster (1, 2 and 3 ) samples (gonad) was determined twice (A and $B$ ). Results for each separate quantitation were plotted on the same graph.
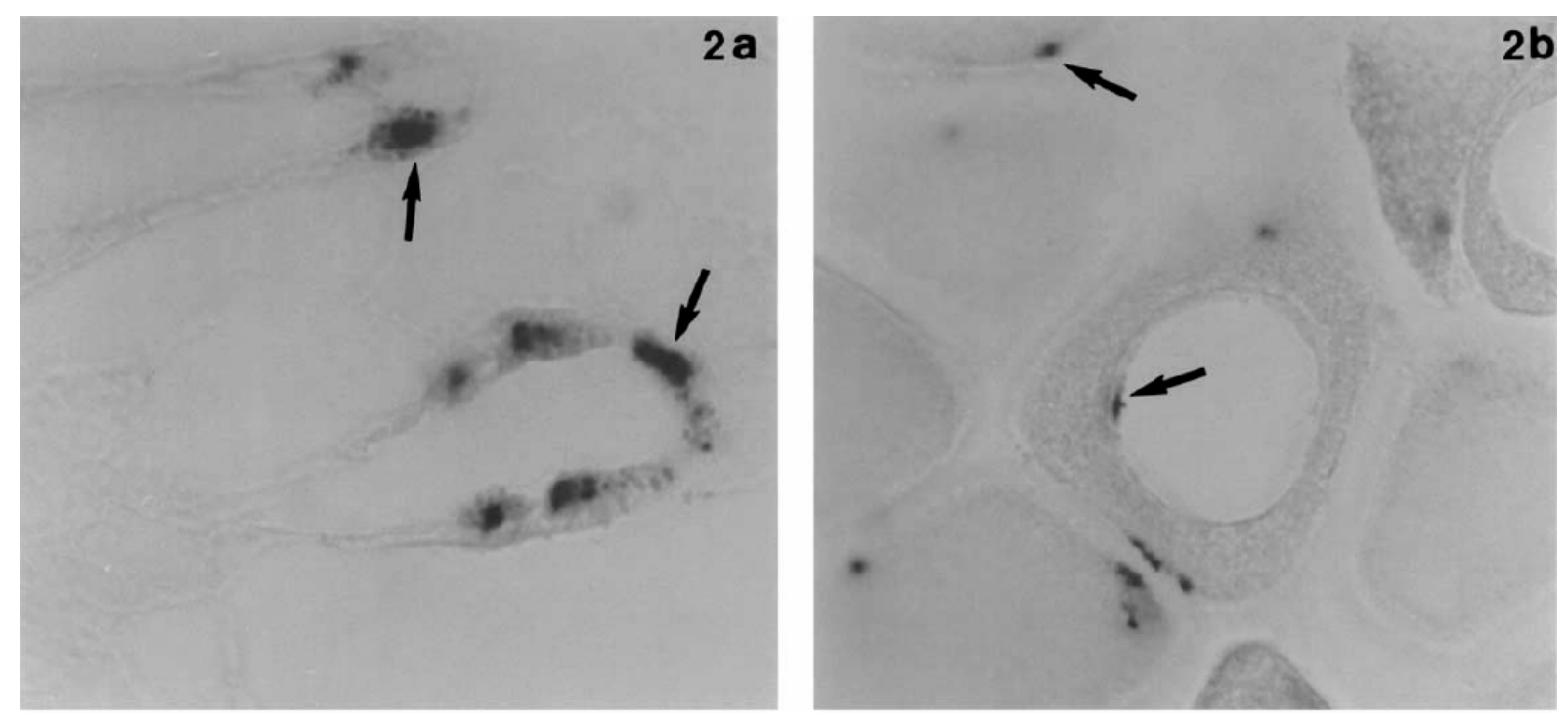

Figures $3 a$ and $b-$ In situ hybridisation results charcaterized by purple (here dark) precipitates. a: positive staining of epithelial gill cells (arrows). b : positive staining in cells of female gonad (arrows). 

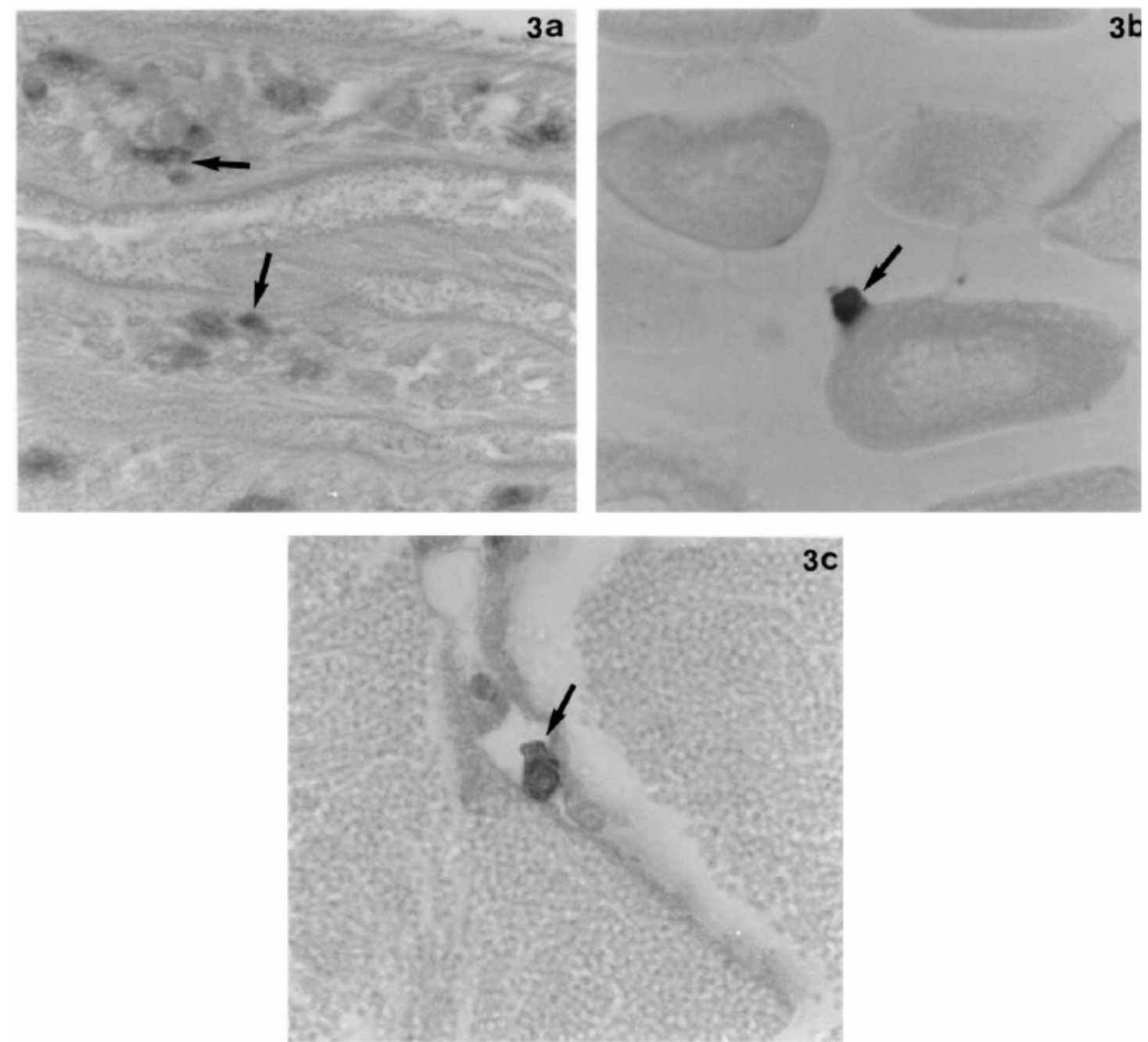

Figures $4 \mathrm{a}, \mathrm{b}$ and $\mathrm{c}-$ Immunochemistry results characterized by brown (here dark) precipitates. a : positive staining in cells of gill connective tissue (arrows). $b$ : positive cell in female gonad connective tissue (arrow). c: positive cell in male gonad connective tissue (arrow). 